\title{
The Free Blacks of Virginia: A Personal Narrative, A Legal Construct
}

Sherri L. Burr

University of New Mexico - School of Law

Follow this and additional works at: https://digitalrepository.unm.edu/law_facultyscholarship

Part of the Law and Race Commons

\section{Recommended Citation}

Sherri L. Burr, The Free Blacks of Virginia: A Personal Narrative, A Legal Construct, 19 The Journal of Gender, Race \& Justice 1 (2016).

Available at: https://digitalrepository.unm.edu/law_facultyscholarship/407

This Article is brought to you for free and open access by the UNM School of Law at UNM Digital Repository. It has been accepted for inclusion in Faculty Scholarship by an authorized administrator of UNM Digital Repository. For more information, please contact amywinter@unm.edu, Isloane@salud.unm.edu,sarahrk@unm.edu.

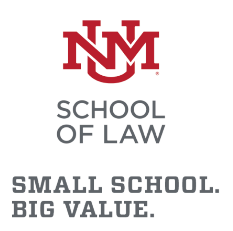

BIG VALUE. 


\title{
The Free Blacks of Virginia: A Personal Narrative, A Legal Construct
}

\author{
Sherri Burr \\ Abstract: The existence of the Free Blacks of Virginia as a \\ group in United States history would surprise most Americans. \\ The common narrative is that all Africans were brought to this \\ country as slaves with no rights, and systematically received \\ legal privileges after the Civil War in the 1860 s and the Civil \\ Rights struggle a century later. The reality differs from this \\ assumption. The first Africans who landed on the shores of \\ Virginia in 1619 began their lives as indentured servants similar \\ to many European immigrants. After finishing their terms of \\ service, these Africans were accorded liberties such as the right \\ to vote, own property, and import both European and African \\ servants. The mid to late $1600 \mathrm{~s}$ brought the legal transformation \\ of Africans from servants for a term to servants for life, or \\ slaves with no rights. The author employs her own family's \\ history in Virginia to illustrate how the initial cluster of Free \\ Blacks grew through manumissions and births at the same time \\ as their legal rights were systematically and dramatically \\ restricted.
}

\footnotetext{
* Sherri Burr is the Dickason Chair in Law at the University of New Mexico School of Law. She hoids an A.B. degree from Mount Holyoke College, a M.P.A. from Princeton University's Woodrow Wilson School of Public and International affairs, and a J.D. from Yale Law School. Burr is also the author of twenty books and the host, producer, and creator of ARTS TALK, a cable access television show focused on the arts. The author thanks University of New Mexico Law School Dean David Herring for granting her a 2014 summer research grant, Associate Dean Nathalie Martin for scheduling a faculty colloquium so the author could present her preliminary findings, and Associate Provost Virginia Scharff for inviting her to present a seven-minute synopsis of her work at the University of New Mexico's Lightning Lounge. Many thanks as well to Cheryl Burbank for her proofreading and cite-checking skills, and to law students Marissa Crollett, Mesa Lindgren, and Laura Melton for their research assistance. The author is grateful to Christa Dierksheide, who wrote Amelionation and Empire: Progress and Slavery in the Plantation Americas, for their meeting at the Jefferson Library in Virginia. Finally, the author expresses appreciation to the following individuals who read parts of the article and provided feedback: Judith Avila, Sue Brown, Melody Groves, Kathleen Hessler, Phil Jackson, Sarena Ulibarri, and Kathy Wagoner.
} 


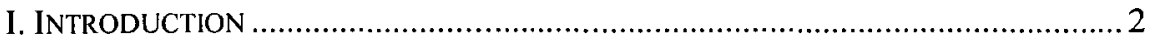

II. FreE BLACKS WITHIN THE UNITED STATES ................................................. 4

Table 1: Free Black Population, 1755-1810 ............................................... 4

Table 2: Proportion of Blacks who were Free, $1755-1810$............................ 5

III. THE BEGINNINGS IN VIRGINIA ….......................................................... 7

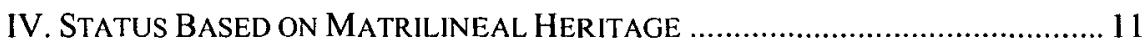

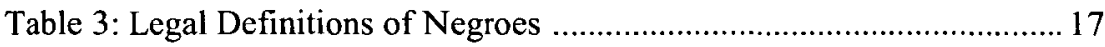

Table 4: Proportion of Free Blacks and Slaves of Mixed Racial Ancestry,

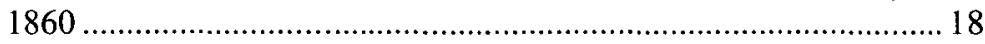

Table 5: The Virginia Population from 1790-1860 ….............................. 25

Table 6: Percentage of Black Population in 1790 ….....................................26

V. THE EFFECT OF THE REVOLUTIONARY WAR ON MANUMISSION

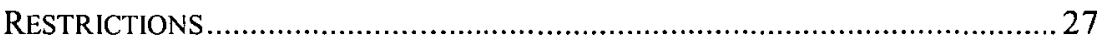

VI. SOCIAL INTERACTIONS BETWEEN FREE BLACKS AND WHITES .................... 32

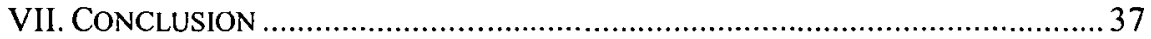

\section{INTRODUCTION}

Some research projects arise from serendipity. The author was on a flight to Salt Lake City to give a speech to the National Federation of Press Women when her seatmate commenced extolling the virtues of the Family History Library. Thinking she would check out the Library for fifteen minutes, the author disembarked from public transportation a stop short of the one nearest to her hotel. Three hours later as the Library was closing and a light drizzle fell in Salt Lake City, the author had missed dinner but hadn't noticed as she left with a stack of documents.

The paperwork contained census records identifying her paternal great-greatgrandfather George W. Hill as having been born free in Virginia in $1847 .{ }^{1} \mathrm{He}$ resided in the household of Gideon Hill who had been born in 1786 and was also identified as a Free Black. ${ }^{2}$ At the top of the census record was the title "Free Inhabitants . . of Virginia." All the blacks and mulattoes were designated with a

\footnotetext{
' Personal details for George W Hill in household number 335 of Gideon Hill, United States Census, 1850 , for the Northern District in the County of Dinwiddie, State of Virginia page 456 (on file with the author).

2 Id. The author capitalizes "Free Black" or "Free Blacks" throughout the manuscript to refer to the unique class of individuals, but does not capitalize blacks or whites, although they refer to a group, unless the word starts a sentence.
} 
$\mathrm{B}$ or $\mathrm{M}$. The whites were not marked. George had an $\mathrm{M}$ next to his name, while a B was marked next to Gideon's name.

Prior to this discovery, the author lacked knowledge that there were blacks born free in the South before the conclusion of the Civil War. Like many Americans, she assumed that all Africans were brought to the South as slaves and their descendants remained so until the conclusion of the Civil War. This led the author to question just how many Free Blacks, like her ancestors, resided in Virginia and the rest of the South during the colonial and antebellum periods. How many Free Blacks lived in the North during this time? What were their lives like? What legal rules governed their activities?

It was the seeking of answers to questions like these that led to this article. Contained within these pages the reader will find historical information on how the class of Free Blacks came to exist, their social interactions with whites, and an analysis of the legal regulations governing their lives. The author's research demonstrates a systematic removal of legal rights from Free Blacks starting in the mid-1600s and continuing up to the start of the Civil War. In 1723, for example, the Virginia colonial legislature abolished voting rights for Free Blacks and Indians, after they had possessed these rights for over a century. ${ }^{3}$ Even though black men were granted the right to vote by the Fifteenth Amendment to the Constitution, ${ }^{4}$ it would take the events accompanying the Civil Rights struggle in Selma, Alabama, before the United States Congress passed the Voting Rights Act in $1965^{5}$ to fully restore these rights. The author concludes by questioning whether the social interactions between whites and Free Blacks, with their ability to manage their financial affairs by owning land and businesses, undercut the racial justification for slavery.

${ }^{3}$ Joan W. Peters, Introduction to JUNE PURCELl GUILD, BLACK LAWS OF VIRGINIA 130 n.9 (Heritage Books 2011) (1936).

${ }^{4}$ The Fifteenth Amendment to the Constitution declared that "[t]he right of citizens of the United States to vote shall not be denied or abridged by the United States or by any state on account of race, color, or previous condition of servitude." It was ratified on February 3, 1870. U.S. CONST. amend. $\mathrm{XV}, \S 1$.

${ }^{5}$ According to the website of the United States Department of Justice,

[t]he Voting Rights Act, adopted initially in 1965 and extended in 1970, 1975, and 1982, is generally considered the most successful piece of civil rights legislation ever adopted by the United States Congress. The Act codifies and effectuates the 15th Amendment's permanent guarantee that, throughout the nation, no person shall be denied the right to vote on account of race or color. In addition, the Act contains several special provisions that impose even more stringent requirements in certain jurisdictions throughout the country.

Introduction to Federal Voting Rights Laws, U.S. DEP'T. OF JUST., http://www.justice.gov/crt/about/ vot/intro/intro.php (last updated Aug. 6, 2015). In recent years, the Voting Rights Act of 1965 has come under attack. In 2013, for example, the U.S. Supreme Court struck down Section 4(b) on the coverage formula as unconstitutional. Shelby County v. Holder, 133 S. Ct. 2612, 2651 (2013). See also ARI BERMAN, GIVE Us THE BALLOT (2015) (detailing other efforts to unravel the Voting Rights Act). 


\section{FREE BLACKS WITHIN THE UNITED STATES}

What was the Free Black population in the United States and Virginia both before and after the Revolutionary War? When the United States undertook its first census in 1790 , as indicated in Table 1 , it revealed that there were nearly 60,000 Free Blacks living in the United States. Within ten years, the population had nearly doubled to over 108,000 and tripled to over 186,000 by 1810 .

\begin{tabular}{|l|l|l|l|l|}
\hline \multicolumn{5}{|c|}{ Table 1: Free Black Population, 1755-18106 } \\
\hline & Pre-1790 & 1790 & 1800 & 1810 \\
\hline United States & & 59,466 & 108,395 & 186,446 \\
\hline North & & 27,109 & 47,154 & 78,181 \\
\hline South & & 32,357 & 61,241 & 108,265 \\
\hline Maryland & 1,817 & 8,043 & 19,587 & 33,927 \\
\hline Virginia & 1,800 & 12,766 & 20,124 & 30,570 \\
\hline
\end{tabular}

Table 1 reveals another interesting fact: more Free Blacks living in the South than in the North between 1790 and 1810, and that fact never changed throughout the entire antebellum period. By 1810 , in the North resided forty-two percent of the Free Blacks in the United States while fifty-eight percent lived in the South.

Why would more Free Blacks choose to reside in the South? It could be that the place of their birth was most familiar and felt like home. The distances were immense when one considers that people traveled by horse, buggy, stagecoach, or boat during this time. Perhaps, the most important considerations were the legal restrictions imposed on their movements, even for such purposes as obtaining an education. States, like Virginia, passed laws stating that if their Free Blacks left the state, they could not return. ${ }^{7}$ Further, Virginia forbade Free Blacks from

\footnotetext{
${ }^{6}$ IRA BERLIN, SLAVES WITHOUT MASTERS 46 (1974).

${ }^{7}$ Chapter 99 (1838) provided,

If free Negroes, whether infant or adult, go beyond the limits of the Commonwealth to be educated, it shall not be lawful for them to retum; if infants they shall be bound out as apprentices until twenty-one years, and then sent out of the state; if adults they shall be sent out of the Commonwealth.
}

GUILD, supra note 3, at 112.

Ten years later, Chapter $120(1848)$ provided, "Any free person of color who shall migrate from the state, or who shall for the purpose of being educated be sent from the state, or who shall for any purpose go to a non-slaveholding state, shall be no longer entitled to residence in Virginia ...." Id. at 117. 
entering their territory from other states. ${ }^{8}$ Indeed, Free Blacks faced whipping, imprisonment, and fines if they returned after having been removed from Virginia. $^{9}$

Table 2 depicts the proportion of blacks who were free as a percentage of total blacks in a particular location. Within the United States in 1790, nearly eight percent of all blacks were free while the other ninety-two percent of their brethren remained enslaved. By 1810 , the number of Free Blacks as a percentage of overall blacks in the United States had risen to nearly fourteen.

\begin{tabular}{|l|l|l|l|l|}
\hline \multicolumn{4}{|c|}{ Table 2: Proportion of Blacks who were Free, 1755-181010 } \\
\hline & Pre-1790 & 1790 & 1800 & 1810 \\
\hline $\begin{array}{l}\text { United } \\
\text { States }\end{array}$ & & $7.9 \%$ & $10.8 \%$ & $13.5 \%$ \\
\hline North & & $40.2 \%$ & $56.7 \%$ & $74 \%$ \\
\hline South & & $4.7 \%$ & $6.7 \%$ & $8.5 \%$ \\
\hline Maryland & $4.0 \%$ & $7.2 \%$ & $15.6 \%$ & $23.3 \%$ \\
\hline Virginia & & $4.2 \%$ & $5.5 \%$ & $7.2 \%$ \\
\hline
\end{tabular}

In Virginia, by contrast, only four and a fifth of a percent of blacks were free prior to 1790 , compared to the approximately ninety-six per cent who were enslaved. By 1790, those numbers had increased to over five and a half percent of all blacks who were free in Virginia whereas about ninety-four and a half percent

${ }^{8}$ Chapter 23 (1793) provided,

This act forbids free Negroes or mulattoes from migrating into the Commonwealth. If they come in, they may be exported to the place from which they came. Every Master of a vessel or other persons who shall bring into this Commonwealth by water or by land any free Negro shall forfeit one hundred pounds, one-half of to the Commonwealth and the other half to the in former.

Id. at 95 .

${ }^{9}$ Chapter 68 (1834) provided,

A free Negro shall not migrate into this Commonwealth from any state in the Union, or from any foreign country, under penalty of thirty-nine lashes on his bare back at the public whipping post. Returning after removal is to be punished according to the act of 1819. Special fines and penalties are set for masters of vessels who bring in any free Negroes. An exception is made for travelers who have any free Negroes in their employment.

Id. at 109.

${ }^{10}$ BERLIN, supra note 6 , at 47. 
remained in bondage. Even though fewer Free Blacks were located in the North, that region had a higher percentage of blacks who were free residing there. The percent rose to seventy-four by 1810 , which meant that twenty-four percent of blacks living in the North were enslaved. Among the most famous northern slaveholders was founding father Benjamin Franklin. ${ }^{11}$ Delaware had the highest percentage of blacks who were free at seventy-six percent whereas Mississippi possessed the lowest percentage of blacks who were free at barely over one percent.

Solomon Northup's book, Twelve Years a Slave, ${ }^{12}$ provides interesting background on the normal life of a Free Black in the North. He writes about his childhood, "I had been principally engaged with my father in the labors of the farm. The leisure hours allowed me were generally either employed over my books, or playing on the violin-an amusement which was the ruling passion of my youth." 13 The activities he mentioned-working on the farm, studying, and playing an instrument-were similar to those occupying the time of all northern free children, whether they were black or white.

Northup also discussed the social relations between Free Blacks and their white neighbors in the North. He wrote of his home in Saratoga Springs, New York, the merchants with whom he contracted, and his friends. ${ }^{14}$ Northup's initial tales were thus of a somewhat normal life as a Free Black in a setting populated primarily by whites. After discussing his birth, his marriage, and his move to Saratoga Springs, Northup wrote, "Thus far the history of my life presents nothing whatever unusual-nothing but the common hopes, and loves, and labors of an obscure colored man, making his humble progress in the world." ${ }^{15}$ Was Northup's life a story that could only take place in the North, or were Free Blacks experiencing similar lives in the South? Were they also contracting business with

11 The website dedicated to Franklin's life wrote,

Benjamin Franklin was a slaveholder for most of his life. The enslaved Africans who are mentioned in Franklin's correspondence include Peter, Jemima, Othello (who died young), King, and George. While he wrote in his 1757 will 'that my Negro Man Peter, and his Wife Jemima, be free after my Decease,' they died before Franklin, who did not own any slaves at the end of his tife. In his later years Franklin became an ardent abolitionist, and in his final will Franklin stipulated that his son-in-law, Richard Bache, should not receive his inheritance unless he freed his slave, Bob.

Benjamin Franklin and Slavery, THE BENJAMIN FRANKLIN TERCENTENARY, http:// www.benfranklin300.org/exhibition/_html/2_2/index.htm (last visited Oct. 12, 2015). According to another publication from this organization, Franklin spent his last years, in part, promoting the abolishment of slavery. Benjamin Franklin: In Search of a Better World, THE BENJAMIN FRANKLIN TERCENTENARY, http://www.ala.org/programming/sites/ala.org.programming/files/content/franklin/ materials/Benjamin_Franklin_Brl.pdf (last visited Oct. 12, 2015).

${ }^{12}$ See generally Solomon NorThup, Twelve YEars A Slave (Penguin Books 2013) (1853).

${ }^{13}$ Id. at 7 .

${ }^{14}$ Id. at 10.

${ }^{15}$ Id. at 11 . 
whites and engaged in neighborly, friendly relations? These questions are worthy of consideration.

In the South and throughout the United States, Virginia's population of Free Blacks was second only to that of Maryland, the southern state closest to the North. Thus, Virginia's legal regulations of Free Blacks and their interactions with whites provide insights into answering the questions above. Virginia became of particular interest to this author after she traced the birth and freedom of her ancestors to the state.

\section{THE BEGINNINGS IN VIRGINIA}

A unique group in United States history, the population constituting the Free Blacks of Virginia began in 1619 with Africans brought to the territory as indentured servants. ${ }^{16}$ In his book, The Free Negro in Virginia, 1619-1865, ${ }^{17}$ Professor Russell wrote that "temporary servitude must be distinguished from slavery. The difference between a servant and a slave is elementary and fundamental. The loss of liberty to the servant was temporary; the bondage of the slave was perpetual." 18 As June Purcell Guild opined, "In the beginning there was no law or custom to define the status of a Negro in the colony; Virginia law on the subject had to be developed and consequently frequently amended." 19

${ }^{16}$ Joan W. Peters, in her forward to June Purcell Guild's book, Black Laws of Virginia, said the group of the first twenty Negroes contained three women. Peters, supra note 3. [Please note, the introductory pages are not numbered.] They were transported by a Dutch frigate. Id.

June Purcell Guild wrote in her introduction to her book, Black Laws of Virginia,

Serving as indentured servants in Virginia were not only Negroes, orphan boys, convicts, workingmen, but some who might truthfully be described as gentlemen. There is nothing to indicate that the position of the Negro was conspicuously different or less comfortable than the lot of most of the others at first.

GuILD, supra note 3, at 9.

She also wrote that in the $1600 \mathrm{~s}$, "White servants were cruelly treated, ran away, were hunted down and branded ...." Id. at 10.

${ }^{17}$ In his book, The Free Negro in Virginia, 1619-1865, Professor Russell also addresses

$[\mathrm{t}]$ he popular misconception of the beginnings of the free $[\mathrm{N}]$ egro population in Virginia . . . as: The first [N] egroes brought to Virginia in 1619 were from the very outset regarded and held as slaves for life. They and all Africans who came after them experienced immediately upon entering Virginia a perpetual loss of liberty.

JoHN RuSSELl, THE FREe NEgRo IN VIRGINIA, 1619-1865, 16 (1913). He added, "This popular error is maintained and supported by a large number of writers who have discussed the introduction of [N]egroes into America." Id.

${ }^{18}$ Id. at 18 .

${ }^{19}$ GUILD, supra note 3, at 7 . 
After serving their term, which could range from four to seven years during the early $1600 \mathrm{~s},{ }^{20}$ Africans were released from servitude and accorded many of the same citizenship rights as former white indentured servants, including the right to own property. In 1623 , Virginia statutes provided, "Every freeman shall fence a quarter of an acre of land to make a garden for planting vines and herbs and mulberry trees." 21 This policy was to ensure that the colony could feed and economically sustain itself. Freeman was the word initially used to reference those who had completed their indentured servitude. ${ }^{22}$

In a major grant of similar rights in 1635 , Virginia permitted Free Blacks to acquire headrights, which granted individuals free acreage based on how many people were available to work their land. ${ }^{23}$ According to the Library of Virginia website, the Virginia Company first established headrights, which were defined as "The right to receive fifty acres per person, or per head," on 18 November 1618 in order to encourage immigration into the colony. ${ }^{24}$ Further, "any person who settled in Virginia or paid for the transportation expenses of another person who settled in Virginia should be entitled to receive fifty acres of land for each immigrant." 25 Planters could claim headrights on each member of their families, including children and servants. ${ }^{26}$ The more individuals a person imported to work their land, the more land they acquired that they could call their own. Individuals and their families could thus accumulate large estates by importing individuals from England, Africa or the West Indies. ${ }^{27}$

Headrights were one of three ways that land was acquired in colonial Virginia. The other two methods were for special services and for consideration, such as the payment of one pound of tobacco per year. ${ }^{28}$

\footnotetext{
${ }^{20}$ In 1642, the Virginia colonial legislature passed the following Act XXVI (1642), which provided, "Servants brought in without indentures shall, if above twenty years serve four years, if they be above twelve years and under twenty years, five years, and if under twelve, seven years." Id. at 38.

${ }^{21}$ Id. at 37.

22 RUSSELL, supra note 17, at 23.

23 The Writer's Program of the Work Projects admin. in the State of VA., The Negro in VIRGINIA 5 (1940). The Writer's Program of the Work Projects Administration in the State of Virginia was established in the midst of the Great Depression to put unemployed professionals to work. Their book contained ex-slave interviews. See Charles Perdue, Forward to The Negro IN VIRGINIA, supra, at vii-ix.

24 See Daphne Gentry, Headrights (VA-NOTES), LIBR. VA. (last visited Oct. 12, 2015), http://www.lva.virginia.gov/public/guides/va4_headrights.htm.

${ }^{25} \mathrm{Id}$.

${ }^{26}$ THE Writer's Program of THE WORK Projects Admin. IN THE STATE OF VA., supra note 23, at 5.

${ }^{27} \mathrm{Id}$.

${ }^{28} / d$.
} 
On 22 July 1634, the Royal Government of Virginia started issuing patents for headrights. ${ }^{29}$ During the early colonial period, blacks could be granted a land patent after completing their indentured servitude for a range of years. A Free Black by the name of Anthony Johnson, for example, was assigned two hundred and fifty acres of land in $1651 .{ }^{30}$ Another Free Black named Richard Johnson remained a servant for only three years, and by 1651 had acquired headrights for his 100 acres of land, which permitted him to import two other people. ${ }^{31}$ Thus Free Blacks took advantage of this opportunity, accorded initially only to their white neighbors, to accumulate land by importing indentured servants from Africa, the West Indies, and England to work for them. ${ }^{32}$

It wasn't until the decade between 1660 and 1670 that Virginia passed laws that transitioned the status of newly arriving Africans from servants for a term to servants for life. This African transition from freedom to enslaved was gradual. Indeed, according to Professor Russell, " $[\mathrm{N}]$ o attempt was ever made to supply legal grounds for holding [N]egroes in a status of slavery." 33

From 1660 to 1670 , slavery went from being sanctioned by customary law to being defined by statute. Starting in 1670 , African servants brought in by ship were considered servants for life if they were not Christian, but servants for a limited time if they were. ${ }^{34}$ This catch- 22 practically guaranteed that all newly arriving Africans would become servants for life unless they somehow had prior knowledge of the rule through exposure to Europeans and their Christian religion, and could speak English.

For white servants, no such distinction was made based on their religious beliefs. Before 1643, white servants without contracts became free after serving two to eight years. ${ }^{35}$ After 1643, the terms were fixed at between four and seven years, depending on the youthfulness of the servant. ${ }^{36}$

In 1670 , however, the Virginia colonial legislature passed a law forbidding Free Blacks from owning white indentured servants, but permitting them the right to continue to own servants of their own race. ${ }^{37}$ Thus, for approximately fifty

\footnotetext{
${ }^{29}$ See Gentry, supra note 24.

${ }^{30}$ RUSSELL, supra note 17 , at 25.

${ }^{31}$ Id.

${ }^{32}$ According to Professor Russell, "the Act of 1670 forbade free [N]egroes to own Christian servants but [conceded] them the right to own servants of their own race." Id. at 33.

${ }^{33} \mathrm{Id}$. at 21 .

${ }^{34} I d$. at 22 . In 1670 , the Virginia legislature passed "An act declaring who shall be slaves," to apply "to servants brought in by ship after 1670 . The test of Christianity was to determine whether they should be servants for a limited time or slaves for life." Id.

${ }^{35} I d$. at 25 .

${ }^{36}$ RUSSELL, supra note 17 , at 25.

${ }^{37}$ GUILD, supra note 3 , at 44 . Act $V$ in 1670 provided, "Negroes or Indians, though baptized and enjoying their own freedom, shall be incapable of purchasing Christians, yet they are not barred from buying any of their color." Id.
} 
years after the arrival of the first Africans in Virginia, Free Blacks possessed many of the same rights as whites after they finished their indentured servitude to acquire indentured servants of both races. The Free Blacks who had indeed imported white indentured servants to work their land were operating within a system set up to encourage the acquisition of as much free or nearly free labor as possible to assist in taming vast quantities of acres. ${ }^{38}$

The Virginia legislature reaffirmed the rule forbidding Free Blacks from owning white indentured servants in 1705 when it passed Act XLIX to proclaim the "Christian care of all Christian slaves." 39 The Act stated that even if a Negro, mulatto, or Indian were Christian themselves, they could not purchase Christian white servants. ${ }^{40}$

Nevertheless, the right of Free Blacks to own other blacks remained for over one hundred and sixty years until 1832, when the Virginia legislature restricted Free Blacks' ownership of slaves with the exception of those acquired through inheritance, or the purchase of a spouse or children. ${ }^{41}$ This meant that Free Blacks could continue to keep those slaves that had been willed to them and to purchase spouses and children who were owned by others. As discussed later in this article, Virginia passed a law in 1806 that discouraged Free Blacks from freeing their relatives because they would be mandated to leave the state within a year and a day of obtaining freedom. ${ }^{42}$

For example, the codicil to Thomas Jefferson's will freed two sons of Sally Hemings and specifically directed his executor to petition the legislature so they could remain in Virginia after his demise. ${ }^{43}$ After freeing John Hemings, Sally's brother, in the prior codicil paragraph, Jefferson wrote,

I also give to John Hemings the services of his two apprentices, Madison and Eston Hemings, until the respective ages of twenty one years, at which period respectively, I give them their freedom, and I humbly and earnestly request of the legislature of Virginia a confirmation of the bequest of freedom to these servants, with permission to remain in the state where their families and connections are, as an additional instance of the

\footnotetext{
${ }^{38}$ The author does not condone indentured servitude or slavery. She uses the right of Free Blacks to import other individuals of multiple races as an example of the early equality between the races that is unknown to many Americans.

${ }^{39}$ GulLD, supra note 3, at 25.

${ }^{40} I d$.

${ }^{41}$ Id. at 107 .

${ }^{42} I d$. at 72 . Chapter 63 (1806) provided, "If any slave hereafter emancipated shall remain within the Commonwealth more than twelve months after his freedom, he shall forfeit such right and may be sold by the overseers for the benefit of the poor." Id. Later the harshness of this law was ameliorated by permitting individuals to petition courts and the legislature to permit emancipated men and women "on proof of their good character and conduct" to remain in Virginia. Id. at 72, n.4.

${ }^{43}$ See Last Will and Testament of Thomas Jefferson, http:/www.monticello.org/site/research-andcollections/last-will-and-testament.
} 
favor, of which I have received so many other manifestations, in the course of my life, and for which I now give them my last, solemn, and dutiful thanks. ${ }^{44}$

In 1827, one year after Jefferson's death, the Virginia legislature honored his last wishes by passing Chapter 139 (1827), which provided,

Burwell, Joe Fossett, John Hemings, Madison and Eston Hemmings, persons of color, emancipated by the will of Thos. Jefferson, deceased, are permitted to remain as free persons within this Commonwealth, provided they are not hereafter convicted by the verdict of a jury and the judgment of the court of an offense against the Commonwealth. ${ }^{45}$

In considering the above information, there existed ample evidence that Free Blacks possessed many of the same civil liberties as whites after they finished their indentured servitude. While the right to own other white indentured servants was removed fifty-one years after the arrival of the first Africans and the right to own black indentured servants and slaves was restricted 213 years after arrival, these rights continued for whites in a slave culture that required free labor to tend the lands.

Free Blacks also presumably held the right to own weapons initially at the conclusion of their indentured servitude. This can be assumed because it was a right that was legally removed in 1639 when by Act $X$, the Virginia colonial legislature provided, "All persons except Negroes are to be provided with arms and ammunition or be fined at the pleasure of the governor and council." 46 The removal of this right would have created hardship for both those who hunted to provide food for themselves and their families, and those who needed to protect themselves from animal and human predators.

Another vexing question arose over time: How should Virginia determine the legal status of those of African descent who were brought to or born in Virginia? The colonial legislature passed numerous laws to address this issue.

\section{Status Based on Matrilineal Heritage}

Prior to 1670, Professor Russell stated, "The status of Africans who came or were brought to Virginia . . was not determined by statute law either before or after that date." ${ }^{47}$ In the 1624 to 1625 census, twenty-three Africans were listed in

\footnotetext{
44 Id. Professor Annette Gordon-Reed analyzes this provision as an example of the preferential treatment Jefferson accorded Sally Hemings' children. It was odd because Madison had already reached the age of 21 , and thus was immediately free. ANNETTE GORDON-REED, THOMAS JEFFERSON \& SAlly Hemings: AN AMERICAN CONTROVERSy 38-39 (1997) [hereinafter Gordon-REed, THOMAS JEFFERSON].

${ }^{45}$ GuILD, supra note 3, at 103.

${ }^{46}$ ld. at 37.

${ }^{47}$ RUSSELL, supra note 17, at 22.
} 
the Virginia colony as servants, and thus received the same class name as many whites. ${ }^{48}$ County records created between 1632 and 1661 designate Blacks as "servants," "negro servants," or simply "negroes," but never as "slaves." 49

To resolve the question of the racial position of those born in Virginia, the colonial legislature passed laws designating that status would be based on matrilineal heritage. ${ }^{50}$ It wasn't until 1662 that the children resulting from the interaction between a white man and an enslaved African woman were considered enslaved. ${ }^{51}$ Act XII read, "Children got by an Englishman upon a Negro woman shall be bond or free according to the condition of the mother . ..."52 Thus, free women gave birth to free children and enslaved women produced enslaved children. ${ }^{53}$

Under these views, the legal status of the father was irrelevant. A white slave master who impregnated his slaves produced more slaves, ${ }^{54}$ but a white woman who had a child by an enslaved person gave birth to a free person. Although the latter was less common, when it did happen the white woman would usually be punished for violating the anti-miscegenation laws and her children would become indentured servants for a term of years until reaching a certain age. ${ }^{55}$

The author's research revealed few incidents of the slave master being punished for sexual relations with slaves. ${ }^{56}$ For example, in 1640 Robert Sweet

\footnotetext{
${ }^{48} I d$. at 23.

${ }^{49} I d$. at 24.

${ }^{\text {so }}$ See GUILD, supra note 3, at 55-56 (Chapter XIV (1748) providing in part, "Children are to be bond or free, according to the condition of their mother.").

${ }^{51}$ RUSSELL, supra note 17 , at 21 .

52 GulLD, supra note 3, at 23.

${ }^{53}$ By law passed in 1662 , Virginia provided that the status of offspring should follow the status of the mother. RUSSELL, supra note 17 , at 37.
}

${ }^{54}$ In statutes passed in 1705 (Act XLIX) and 1753 (Chapter VII), Virginia prohibited white men and women from marrying a Negro. They were "to be committed to prison for six months without bail, and pay 10 pounds to the use of the parish." See GuILD, supra note 3, at 25-27.

55 These laws became predecessors for those passed after the Civil War when whites and blacks were
also expressly forbidden to marry. In 1885 , a Virginia County Court sentenced Isaac Jones, a Negro,
to the penitentiary for two years and nine months for the felonious marriage to Martha Gray, a white
woman. See Jones v. Commonwealth, 80 Va. 538 ( 1885 ). The marriage was considered "against the
peace and dignity of the commonwealth" and violated a statute that provided, "Any white person who
shall intermarry with a [N]egro, and any [N]egro who shall intermarry with a white person, shall be
confined to the penitentiary not less than two nor more than five years." Id. at $541-42$. Jones appealed
his sentence on the grounds that the Court failed to prove that he was a Negro. Id. Since the county
produced no evidence that he was a Negro, the court said that he was presumed not to be, and therefore
he was assumed innocent. Id. at $544-45$. The court's rationale was that a man of mixed blood was not
a Negro unless the Commonwealth proved that he had at least one-fourth of Negro blood in his veins.
Id. In this case, the Commonwealth had offered no evidence to prove its case. Id. In modern times, the
most well-known case became that of Loving $v$. Virginia, 388 U.S. 1,12 (1967), in which the U.S.
Supreme Court expressly invalidated prohibitions against interracial marriage.

${ }^{56}$ After the Civil War, several laws were passed prohibiting the marriage between blacks and whites. In 1877, the Commonwealth of Virginia charged Rowena McPherson and George Stewart with having 
was ordered to do penance in church according to the laws of England for impregnating a black woman with a child, and the woman was ordered whipped. ${ }^{57}$

In Meghan Carr Horrigan's article, The State of Marriage in Virginia History: A Legislative Means of Identifying the Cultural Other, she argued that Virginians were less concerned with black women bearing mixed children than they were with white women bearing mixed children. ${ }^{58}$ In both instances, the result was a child whose parents were black and white, but Horrigan maintained that Virginia viewed white women as the keepers of racial purity. ${ }^{59}$

In 1691, the Virginia colonial legislature passed Act XVI to forbid intermarriage between people of color and whites. The specific Virginia legislation stated, "whatsoever English or other white man or woman, bond or free, shall intermarry with a Negro, mulatto, or Indian man or woman, bond or free, he shall within three months be banished from this dominion forever."60 Consequently, within this time period if a free white person married a Free Black, they would both be exiled from Virginia.

The Act stated that it was designed to prevent the "abominable mixture and spurious issue which hereafter may increase" as a result of such intermarriage. ${ }^{61}$ Moreover, Act XVI, in 1691, provided that any free white woman who had "a bastard child by a Negro ... shall pay fifteen pounds to the church wardens, and in default of such payment, she shall be taken into possession by the church wardens and disposed of for five years." 62 Her child would also "be bound out by the church wardens until he is thirty years of age," making both mother and child servants for a term. ${ }^{63}$

Since blacks and whites could not marry, these laws guaranteed that any children resulting from such unions would be illegitimate. The parents could be imprisoned, and depending on the status of the mother, the children would be either enslaved or indentured for a term of years before obtaining their freedom. The harsh legal approach to the couple guaranteed that their children would suffer by not being raised by parents who loved them.

illicit intercourse with each other. See McPherson v. Commonwealth, 69 Va. 939, 939 (1877). Their defense was that the couple was married. Id. The issue became whether Rowena was a Negro, which would make her marriage to George Stewart, a white man, illegal. $I d$. at 940 . The court decided that because McPherson was less than one-quarter Negro, she was not considered a Negro under the statute. Id. McPherson's father was white, her mother's father was white, and her great-grandmother was of brown complexion. $I d$.

${ }^{57}$ GuILD, supra note 3, at 21.

${ }^{58}$ Meghan Carr Horrigan, The State of Marriage in Virginia History: A Legislative Means of Identifying the Cultural Other, 9 GEO. J. GENDER \& L. 379, 383 (2008).

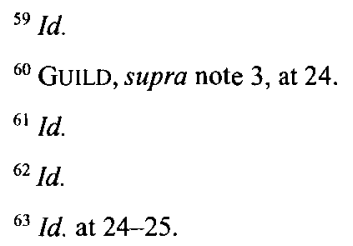


If a married white woman delivered a mulatto child, her marriage to her white husband could be dissolved ${ }^{64}$ In 1803 , the Virginia legislature passed Chapter 6 , which provided:

The marriage between Benjamin Butt, Jr., and a certain Lydia Bright, who is of respectable family, and was at the time of the marriage supposed to be unsullied in her reputation, is dissolved because Lydia has been delivered of a mulatto child and has publicly acknowledged that the father of the child is a slave. ${ }^{65}$

In 1814, the Virginia legislature passed Chapter XCVIII dissolving the marriage of Richard and Peggy Jones, "provided that a jury find that the child of Peggy is not the child of Richard, but is the offspring of a man of color." 66

Perhaps Lydia Bright and Peggy Jones were fortunate that their husbands chose to seek legal dissolution of their marriages after they had given birth to children of color. In modern times, it may be hard to contemplate the shock the husbands experienced after seeing what they thought were their children for the first time. Not only had their wives deceived their husbands, but they had also presumably betrayed their race by having sexual relations with persons of color.

Both adultery and miscegenation were expressly punished in Virginia at the time. In 1792, Virginia legislature passed Chapter 72 to provide that every person committing adultery or fornication shall forfeit twenty dollars for adultery and ten dollars for fornication if convicted. ${ }^{67}$ White men and women who married either free or enslaved blacks could be committed to prison for six months and fined thirty dollars. ${ }^{68}$

Despite legal prohibitions, blacks and whites continued to intermingle and produced mixed-race children into the second and third generations. The Virginia legislature addressed the question of how to define the resulting racial combinations. In 1785, the Virginia legislature defined a Negro as a person possessing one-fourth or more Negro blood. ${ }^{69}$ Those with less than one-fourth

\footnotetext{
64 See id. at 31 .

${ }^{65} \mathrm{Id}$.

${ }^{66}$ GulLD, supra note 3, at 31.

${ }^{67}$ Id. at 30-31. Chapter 72 provides, "Every person not being a servant or slave committing adultery or fornication, and being convicted by the oaths of two or more credible witnesses or confession of the party, shall forfeit $\$ 20.00$ for adultery and $\$ 10.00$ for fornication." Id.

${ }^{68}$ Id. at 30. Chapter 42 (1792) provided,
}

For preventing white men and white women intermarrying with Negroes or mulattoes, it is enacted that whatsoever white man or woman, being free, shall intermarry with a Negro Man or woman, bond or free, he or she shall be committed to prison for six months, and pay $\$ 30.00$ for the use of the parish. The penalty for a minister marrying Negroes and whites is set at $\$ 250$ for each such marriage.

Id.

${ }^{69} I d$. at 29 . The act that entered into force on January 1, 1787, provided, 
Negro blood who, for example, had a great-grandparent who was half or full Negro were presumed to be white at this time. ${ }^{70}$

By this definition, Sally Hemings, who was one of the most famous enslaved persons because of her connections to Thomas Jefferson, ${ }^{71}$ was considered a mulatto because she was three-quarters white and one-quarter African. ${ }^{72}$ Moreover, by this same definition, her children with Thomas Jefferson, which have been confirmed with DNA testing and documentary evidence, ${ }^{73}$ would be

Every person of whose grandfathers or grandmothers anyone is or shall have been a Negro, although all his other progenitors, except that descending from the Negro shall have been white persons, shall be deemed a mulatto, and so every person who shall have one-fourth or more Negro blood shall in like manner be deemed a mulatto.

ld.

${ }^{70}$ See id. This presumption would change over time. For example, in June 1892, Homer Plessy who was one-eighth Negro was jailed for sitting in the white section of the train in New Orleans. See Plessy v. Ferguson, 163 U.S. 537 (1896). The U.S. Supreme Court proclaimed the "separate but equal" doctrine when it upheld Louisiana's "Separate Car Act." Id.

${ }^{71}$ Sally Hemings has been featured in numerous non-fiction books, and became the main character in at least one work of fiction, namely BARBARA CHASE-RIBOUd, SALLY HEMINGS (1979). Some of the non-fiction works include GORDON-REED, THOMAS JEFFERSON, supra note 44, and ANNETTE GORdON-REED, THE HEMINGSES OF MONTICELlo: AN AMERICAN FAMILY (2009) [hereinafter Gordon-ReEd, The Heminges]. The latter won the National Book Award and a Pulitzer Prize. An entire section, with multiple chapters, is devoted to Sally Hemings in VIRGINIA SCHARFF, THE WOMEN JEFFERSON LOVED 157-236 (2010). The story of Sally Heming's relationship with Thomas Jefferson is featured in Fawn Brodie, ThOmas JefFERSON: AN INTIMATE History 228-245 (1974). These works differed substantially from the early writings about Sally Hemings from many male historians who sought to deny that a relationship had existed between her and Thomas Jefferson. The female historians, by contrast, analyzed the documentary evidence and presented the case that a love relationship existed between Sally Hemings and Thomas Jefferson that lasted over several decades, beginning when he was ambassador to Paris and continuing through his presidency, his retirement from public life, and his retum to Monticello. The relationship was well-known in Virginia and little discussed until Jefferson became president. It was then that it became the subject of scandal. GordonReed's book, Thomas Jefferson \& Sally Hemings, devotes a chapter to James Callender who "made the first public allegation that Jefferson had been involved in a sexual relationship with Sally Hemings." GORDON-REED, THOMAS JEFFERSON, supra note 44, at 59, 59-77.

72 See GORDON-REED, HEMINGSES OF MONTICELLO, supra note 71, at 667-69 (showcasing the family tree of Sally Hemings). In the family tree, Sally's parents were Betsy Hemings, a half-African, halfEnglish slave and her father was John Wayles. Id.

73 The November 5, 1998, issue of the scientific journal Nature confirmed a genetic link between the descendants of Eston Hemings, Sally's son, and the descendants of Field Jefferson, whereas there was no genetic link between the Hemings descendant and that of the Carrs, Jefferson's nephews who had been put forward by his family as the fathers of Sally Hemings' children. See GORDON-REED, THOMAS JEFFERSON, supra note 44, at ix-X. For documentary evidence, Annette Gordon-Reed links Thomas Jefferson's travels to Monticello with the timing of the conception of Sally Hemings' children:

The pattern went like this: Jefferson comes home for six months and leaves. Hemings bears a child four months after he is gone. Jefferson comes home for six weeks. Hemings bears a child eight months after he's gone. Jefferson comes home for two months and leaves. Hemings bears a child eight months after he is gone. This went on for fifteen years through six children. He was there when she conceived, and she never conceived when he was not there.

Id. at $100-01$. 
considered white since they were only one-eighth Negro. ${ }^{74}$ Jefferson even opined that once someone possessed only one-eighth Negro blood, or "three crossings" with whites, they should be considered white. ${ }^{75}$

By statute, the Virginia Legislature would sometimes proclaim a person to be white. An 1833 statute specifically declared that parties named Wharton were "not Negroes or mulattoes but white persons, although remotely descended from a colored woman."76 The Whartons, for example, had previously been held in slavery but had acquired their freedom in $1806 .{ }^{77}$

Even after the Civil War in 1866 , the Virginia legislature reiterated that people "having one-fourth or more Negro blood shall be deemed a colored person," and a person "having one-fourth or more Indian blood shall be deemed an Indian." 78 By 1910, Virginia lowered the blood quantum separating blacks and whites to one-sixteenth. ${ }^{79}$ Eventually the Virginia legislature passed Chapter 371 , to provide, "For the preservation of racial integrity" requiring registration certificates for those born before June 14, 1912 to show their racial purity ${ }^{80}$ In

\footnotetext{
${ }^{74}$ Madison Hemings, a son who resulted from this union, gave an interview to a radical Republican newspaper editor in 1873 in which he retold the story of how his mother became Mr. Jefferson's concubine while the two were in France. See SCHARFF, supra note 72, at 214-15. He said he had lost contact with Beverly and Harriet who both passed as whites and married whites in "good circumstances" or in "good standing." GORDON-REED, THOMAS JEFFERSON, supra note 44, at 246.
}

75 Gordon-REed, ThOMAS JefFerson, supra note 44, at 53 ("In 1815 , in a letter correcting an erroneous statement of law that he had made to a man who had asked when a black person could be considered a white person under the laws of Virginia, Jefferson wrote out an algebraic equation demonstrating that after 'three crossings' with whites, the black person was legally white.").

In her work, Professor Gordon-Reed masterfully argues for a loving connection between the two individuals that produced four children who survived into adulthood. Id. at 166-72. Three of the children (Beverly, Harriet, and Eston) passed as whites, whereas Madison embraced being black. See generally $i d$. at 246-48. Gordon-Reed chronicles the impregnation of Sally with the times she and Jefferson were in France together and when he was at Monticello and the subsequent birth of her children within nine months. Id. at 100-01. Sally never conceived during a time when Jefferson had no access to her. Id. Gordon-Reed also repeated a Fawn Brodie claim that one of Jefferson's grandsons had said that all of Sally Hemings's children "looked like Jefferson, one of them so closely that if he was seen at twilight, one might mistake him for Jefferson." Id. at 50.

${ }^{76}$ GuILD, supra note 3 , at 32 .

${ }^{77}$ Id.

${ }^{78} I d$. at 33.

${ }^{79}$ Id. at 35 (citing Chapter 357 (1910)) ("Every person having one-sixteenth or more Negro blood shall be deemed a colored person, and every person not a colored person having one-fourth or more of Indian blood shall be deemed an Indian.").

${ }^{80}$ Id. at 35. Chapter 371 (1924) further directed:

No marriage license shall be granted unless the clerk has reasonable assurance that the statements as to color are correct. It shall be unlawful for any white person to marry any save a white person, or a person with no other admixture of blood than white and American Indian. The term "white person" shall apply only to the person who has no trace whatsoever of any blood other than Caucasian, but persons who have one-sixteenth or less of the blood of the American Indian, and no other non-Caucasic [sic] blood shall be deemed white persons. 
1930, the Virginia legislature would lower the percentage of blood quantum from one-sixteenth to one drop by providing, "[e]very person in whom there is ascertainable any Negro blood shall be deemed a colored person." 81 These changes are depicted in Table 3 :

\begin{tabular}{|l|l|l|}
\hline \multicolumn{3}{|c|}{ Table 3: Legal Definitions of Negroes } \\
\hline Year & Percent of Negro Blood & Ancestor requirement \\
\hline 1785 & One Fourth & $\begin{array}{l}\text { At least one } \\
\text { grandparent }\end{array}$ \\
\hline 1910 & One Sixteenth & $\begin{array}{l}\text { At least one great- } \\
\text { great grandparent }\end{array}$ \\
\hline 1930 & One Drop & Any ancestor \\
\hline
\end{tabular}

As mentioned earlier, despite these considerable attempts to legislate the prohibition of sexual contact between blacks and whites, the continued intermixing of the races contributed to the growth of the mulatto population. ${ }^{82}$ In the deeper South, like Louisiana and Mississippi, arguably more children were likely produced by white men's dalliances with slave women. They had considerable access to these women and, because the women were considered as property, they could not say "No," even when confronted by the anger of the man's wife. ${ }^{83}$ That said, Free Blacks were more likely to be of mixed ancestry than were slaves.

Id. Horrigan contends that this act was the beginning of the one-drop rule in Virginia, and that the time frame overlapped with the eugenics research that claimed to prove the inferiority of black and native people. Horrigan, supra note 58 , at 389 . An irony is that they considered Black blood to be genetically dominant and thus one drop could contaminate and corrupt an otherwise white race. $I d$.

${ }^{81}$ GuILD, supra note 3, at 35-36.

${ }^{82}$ In his work Free African Americans of North Carolina, Virginia, and South Carolina: From the Colonial Period to About 1820, Paul Heinegg maintains that the sexual relations between white men of property and servant and slave women "produced a scant one percent of the free children of color." Ira Berlin, Foreward to PaUl HeinegG, 1 Free African AmEricans of North Carolina, ViRginia, AND SOUTH CAROLINA: From THE COlonial PERIOD to ABOUT 1820, v (5th ed. 2005). Instead, he demonstrates "most free people of color had their beginnings in relations between white women (servant and free) and black men (slave, servant, and free). These relations, moreover, often presented long-term and loving commitments." Id. at v-vi.

${ }^{83}$ In his book, Twelve Years a Slave, Solomon Northup depicts the horrid life of the slave woman Patsey about whom he wrote,

Patsey wept oftener, and suffered more, than any of her companions. She had been literally excoriated. Her back bore the scars of a thousand stripes; not because she was backward in her work, nor because she was of an unmindful and rebellious spirit, but because it had fallen to her lot to be the slave of a licentious master and a jealous mistress. She shrank before the lustful eye of the one, and was in danger even of her life at the hands of the other, and between the two, she was indeed accursed.

NORTHUP, supra note 12, at 123. For playing the role of Patsey, Lupita Nyong'o won the 2014 Academy Award for Best Performance by an Actress in a Supporting Role. Christopher Rosen, Lupita Nyong 'o. Best Supporting Actress Oscar Winnner at 86 th Annual Academy Awards, THE HUFFINGTON 
Table 4 indicates the proportion of Free Blacks and slaves of mixed ancestry on the eve of the Civil War in 1860. The contrast between the mixed race status of Free Blacks in Virginia and Louisiana is startling, with twice as many Free Blacks being of mixed ancestry in Louisiana.

\begin{tabular}{|l|l|l|}
\hline \multicolumn{2}{|c|}{ Table 4: Proportion of Free Blacks and Slaves of Mixed Racial } \\
Ancestry, 1860 \\
\hline & Free [Blacks] & Slaves \\
\hline United States & $36.2 \%$ & \\
\hline North & $30.9 \%$ & \\
\hline South & $40.8 \%$ & $10.4 \%$ \\
\hline Virginia & $40.5 \%$ & $14.3 \%$ \\
\hline Kentucky & $38.1 \%$ & $19.2 \%$ \\
\hline Louisiana & $81.3 \%$ & $9.8 \%$ \\
\hline
\end{tabular}

This may indicate that slave owners were more likely to set free those mulattos they had fathered in Louisiana, whereas in Virginia slave owners were more likely to manumit blacks because they felt it was morally or religiously appropriate.

Previously, the author mentioned that her ancestor Gideon Hill was designated in the 1850 census as Black and her great-great grandfather George Hill as mulatto. After further investigation, she was able to determine that Mary, Gideon's Daughter, who was designated as Black, was the mother of George and his older brother John. This meant that their father was most likely white. Mary had two children by this man in an era when whites and blacks could not legally marry and thus legitimize their relationship and their children. In the 1860 census, John and George are listed as living as laborers in the home of a white male who might have been biologically connected to them.

According to Professor Russell, the Free Black population grew from five sources: (1) children born to free parents; (2) Mulatto children born of Free Black mothers; (3) Mulatto children born of white servant or free women; (4) children of Free Black and Indian mixed parentage; and (5) manumitted slaves. ${ }^{85}$ In his

POST (Mar. 3, 2014), http://www.huffingtonpost.com/2014/03/02/lupita-nyongo-best-supportingactress_n_4844078.html.

${ }^{84}$ Berlin, supra note 6, at 178 (citing U.S. Bureau of THE CEnSUS, Negro Population of the UNITED STATES, 1790-1915 220 (1918)) (portions of the table omitted).

${ }^{85}$ RUSSELL, supra note 16 , at $40-41$. 
first four categories, all the children were born to free mothers, whether they were black, white or mulatto. This was the primary avenue of growth during certain parts of Virginia's colonial history. It was the fifth category that required legal action on the part of the slave owner, and the right was either permitted or restricted depending on legislative control. A slaveholder would have to file a deed during his or her life to set someone free or could do so in a last will and testament.

In the 1600 s and early 1700 s, as the population of Free Blacks grew significantly from births to free women, white Virginians became so concerned about the number of Free Blacks in their territory that legislators started adopting laws restricting liberties to manumit slaves. ${ }^{86}$ In 1734, Virginia completely prohibited the manumission or emancipation of slaves, with the exception of those who had performed some meritorious services to be determined by the governor and council. ${ }^{87}$ In 1779 , for example, the legislature declared that a "slave named Kitt, owned by Hinchia Mabry, of Brunswick, has rendered meritorious service in making the first information against several counterfeiters, and is hereby emancipated and his owner ordered paid 1,000 pounds out of the public treasury." 88

Since slaves were considered valuable property, setting them free potentially involved financial sacrifice. In the Kitt example, the legislature purchased his freedom because he exposed counterfeiters. ${ }^{89}$ Initially, the slaves were compared

\footnotetext{
${ }^{86}$ Chapter XVl (1691) provided, "Negroes who are set free must be transported out of the county by the person giving them freedom within six months after such setting free." GulLD, supra note 3 , at 94 In 1831, the legislation became harsher. Chapter XXXIX (1831) provided, "Free Negroes and mulattoes who remain in the Commonwealth contrary to law are to be sold publicly." $I d$. at 106 . Thus, Free Blacks who did not depart Virginia risked re-enslavement.
}

${ }^{87}$ Chapter IV (1723) provided, in part

No Negro or Indian slave shall be set free upon any pretence whatsoever, except for some meritorious services, to be adjusted by the governor and council, and a license thereupon obtained. If a slave is set free otherwise than as directed, the church wardens are required to take up and sell the individual as a slave by public outery and the monies shall be applied to the use of the parish.

Id. at 53 .

88 A. LEON Higginbotham, JR., IN THE MATter OF COLOR: RACE AND tHE AMERICAN LEGAL PRoCESS: THE COLONIAL PERIOD 49 (1978).

${ }^{89} \mathrm{Id}$. 
to realty ${ }^{90}$ and later to personal property. ${ }^{91}$ Owners paid taxes on all of their slaves. ${ }^{92}$ Free Blacks paid personal taxes. ${ }^{93}$

Laws enacted in 1691 and 1723, which remained in effect until 1782, limited the increase of Free Blacks "to natural means and to manumissions by special legislative acts." 94 An example occurred in 1810 when the legislature set free a widow and the children of Frank, a Free Black, who had died leaving his family

${ }^{90}$ Chapter XXIII (1705) provided, in part,

All Negro, mulatto, and Indian slaves within this dominion shall be held to be real estate and not chattels and shall descend unto heirs and widows according to the custom of land inheritance, and be held in fee simple. Provided that any merchant bringing slaves into this dominion shall hold such slaves whilst they remain unsold as personal estate. All such slaves may be taken on execution as other chattels; slaves shall not be escheatable.

GuILD, supra note 3, at 48 . The latter phrase references the normal right of the state to take property if heirs cannot be found. Under this provision, the territory of Virginia forfeited the right to receive slaves if heirs could not be found.

${ }^{91}$ Chapter II (1748) provided, "Negroes having been declared to be real estate in 1705 and afterward this explained by act in 1727 and the acts having been found inconvenient, they are repealed, and for the future all slaves shall be taken to be chattels." $I d$. at 55 .

${ }^{92}$ Act VII (1705) provided,

It is enacted that all male persons of the age of sixteen years and upward, and all Negro, mulatto, and Indian women of sixteen years, not being free shall be tithable or chargeable for defraying the public, county, and parish charges in this her majesty's colony and dominion, excepting such only as the county court and vestry for reasons in charity shall think fit to excuse. Every master or mistress shall, under penalty, by a list cause to be delivered to the justice the name of all tithable persons belonging to his or her family.

Id. at 131 .

${ }^{93}$ Act VII (1668) provided, "Negro women though permitted to enjoy their freedom, yet ought not in all respects to be admitted to full fruition of the exemptions of the English and are still liable to the payment of taxes." Id. at 129. Chapter IV (1723) provided, "All free Negroes, mulattoes, and indians (except tributary Indians to this government), male and female above sixteen years of age, and all wives of such, shall be deemed tithables." Id. at 131. This same act removed the right of Free Blacks to vote, by providing, "No free Negro or Indian whatsoever shall hereafter have any vote at any election." Id. at 132.

${ }^{94}$ RUSSELL, supra note 17, at 10. Act XVI (1691), provided, in part,

A great inconvenience may happen to this country by the setting of Negroes and mulattoes free, by their entertaining Negroes from their masters' service, or receiving stolen goods, or being grown old bringing a charge upon the country, it is enacted that no Negroes, or mulattoes be set free by any person whatsoever, unless such person pay for transportation of such Negro out of the country within six months after such setting free, upon penalty of ten pounds sterling to the church wardens, with which the church wardens are to cause the Negro to be transported out of the country and the remainder given to the use of the poor of the parish.

GuILD, supra note 3, at 47. 
in bondage ${ }^{95}$ Eventually, after the law was amended in 1782, some Africans who were servants for life were granted their freedom through deeds and wills.

The author's family ancestry illustrates the first and fifth categories of how the Free Black population increased in Virginia. The 1850 census record, where the author found the name of her great-great-grandfather George W. Hill, listed everyone living in the household of Gideon Hill as free. ${ }^{96}$ In the 1840 census, Gideon Hill's household included eight "Free Colored Persons," with one male under 10, another between the ages of twenty and twenty-four, and Gideon who was between the ages of twenty-five and fifty-five. ${ }^{97}$ His household also included three females under the age of ten, one female between the ages of ten and twentyfour, and one between the ages of twenty-five and fifty-five, presumably who was Gideon's wife. ${ }^{98}$

Because Free Blacks were required to register as of $1793,{ }^{99}$ the author acquired physical descriptions of some of her collateral and direct relatives. In 1853, Nancy Hill registered as a daughter of Gideon Hill when she was age sixteen: her color was designated as black and her height listed as four-feet, eleven inches tall, she possessed no mark or scar on her head, face or hands, and she answered the question seeking how she acquired her freedom by replying that she was born free. ${ }^{100}$

Like Nancy, her sister Julia Hill who registered on March 9, 1855, indicated she was born free. Julia was nineteen at the time, and her color was brown while her height noted at five-feet, six-inches. Unlike the flawless Nancy, Julia was described as having "a small scar on her [w]right wrist." ${ }^{101}$ When Julia married John Bronwell on 17 May 1866, approximately a year after the conclusion of the

${ }^{95}$ Chapter LVIII (1810) provided,

A certain free man of color, by the name of Frank, has died, leaving in bondage a widow, Patience, and three children, whom Frank, by meritorious industry, purchased in his lifetime, but failed to emancipate; it is enacted by the General Assembly that Patience and the children shall be free.

GulLD, supra note 3, at 96. Frank, probably, did not free Patience and their children because they would have been forced to leave the state.

${ }^{96}$ Personal details for George W Hill in household of Gideon Hill, supra note 1.

${ }^{97}$ Id.

98 ld.

${ }^{99}$ Peters, supra note 3 . The General Assembly passed legislation to register all free Negroes and mulattoes in the Commonwealth with the clerk of the Court in the community in which they lived. The register was required to record name, age, color, status and emancipation details, such as by whom and in which county court the registrant had been freed. Id. The law required Free Negroes and mulattoes to re-register every three years. If they remained unregistered, they risked being jailed as runaway slaves. In 1834, the law was amended to require the register to include notes of marks and scars in the description of the registrant. $I d$.

${ }^{100}$ Free Black Registry Information on Nancy Hill (Feb. 24, 1853) (on file with the author).

${ }^{101} I d$. 
Civil War, she listed her age as thirty-two and stated her parents were Celia and Gideon Hill. ${ }^{102}$

When Gideon Hill registered in 1856 , he said that he had obtained his freedom from Ben Crawley. ${ }^{103}$ From the Library of Virginia, the author obtained a deed signed by Ben Crawley on 25 January 1787. The document began with the words, "Know all men by these presents that I Benjamin Crawley of Amelia County in the state of Virginia by virtue of the Act of Assembly in that ease made and provided do hereby emansipate [sic] and set free from bondage the following slaves or servants ...."104 The list included "Geddy aged two."105 The timing of Mr. Crawley's emancipation deed followed by five years the act of Virginia permitting such emancipations after they had been severely restricted starting in $1723 .{ }^{106}$

Up until 1723, Blacks could be set free by public and private acts of manumission. Chapter IV (1723) provided, "No Negro or Indian slave shall be set free upon any pretence whatsoever, except for meritorious services, to be [adjudicated] by the governor and council, and a license thereupon obtained." 107 The statute further asserted, "If a slave is set free otherwise than as directed, the church wardens are required to take up and sell the individual as a slave by public outcry and the monies shall be applied to the use of the parish." 108

The Virginia legislature sometimes passed statutes that set people free. In 1710, for example, the Virginia legislature passed a law setting free Will for his service in helping to disrupt a slave conspiracy. ${ }^{109}$ The ultimate act of manumission was the Emancipation Proclamation which proposed to set free all

\footnotetext{
${ }^{102}$ Marriage Registration Information for Julia Hill (May 17, 1866) (on file with the author).

${ }^{103}$ Free Black Registry Information on Gideon Hill, supra note 100.

${ }^{104}$ Benjamin Crawley's Deed of Emancipation (Jan. 25, 1787) (on file with the author).

${ }^{105} \mathrm{Id}$.

${ }^{106}$ Chapter XXI (1782) provided, "It is lawful for any person by last will and testament or other instrument in writing sealed and witnessed to emancipate and set free his slave or slaves." GUILD, supra note 3 , at 61 .

${ }^{107}$ GuILD, supra note 3, at 53.

108 ld.

${ }^{109}$ Id. at 52. Chapter XVI (1710) provided:
}

Whereas a Negro slave named Will, belonging to Robt. Ruffin, of the county of Surry, was signally serviceable in discovering a conspiracy of Negroes for levying war in this colony; for a reward of his fidelity, it is enacted that the said Will is and forever hereafter shall be free and shall continue to be within his colony, if he think fit to continue. The sum of forty pounds sterling shall be paid the said Robt. Ruffin for the price of Will.

Id. What the colonial legislature viewed as meritorious service, the other Negroes probably viewed Will's actions as treachery. Probably, they were severely punished. In 1748, the legislature passed Chapter XXXVIII, which states, "The conspiracy of slaves or their insurrection is a felony and the penalty death without benefit of clergy." Id. at 57. 
southern enslaved blacks on January $1,1863 .{ }^{110}$ The Proclamation did not apply to slaves held in the North because they were not in rebellion. ${ }^{111}$

Privately, people manumitted slaves during their lives, by deed, or after their death, by their last will and testament. ${ }^{112}$ Professor Russell estimated that there were less than 3,000 Free Blacks when the restraint on manumission was removed in 1782 , but within eight years, the population quadrupled to $12,886 .{ }^{113} \mathrm{As}$ an example, Russell cited William Binford and Robert Pleasants, of Henrico County, who respectively manumitted twelve and ninety slaves in $1782 .{ }^{114}$

It was only after the law changed that one of the author's ancestor, Gideon Hill, who was about two years old, was manumitted by a deed signed by Benjamin Crawley in 1787. This deed freed fifty slaves at once, including presumably Gideon's parents and several other relatives. Thus, when the first United States census was taken in 1790, the author's relatives were free.

In contrast to his deed of emancipation in 1787, in his last will and testament Benjamin Crawley bequeathed fifteen slaves to his nephew David Crawley Jones. ${ }^{115}$ The document said that all of the Negroes had been given to him by his late brother John in his last will and testament. Benjamin Crawley's last will and testament also gave other property to his nephew that had been left to him by his brother John. ${ }^{116}$

\footnotetext{
${ }^{110}$ The Emancipation Proclamation read, in part,

That on the first day of January, in the year of our Lord one thousand eight hundred and sixty-three, all persons held as slaves within any State or designated part of a State, the people whereof shall then be in rebellion against the United States, shall be then, thenceforward, and forever free; and the Executive Government of the United States, including the military and naval authority thereof, will recognize and maintain the freedom of such persons, and will do no act or acts to repress such persons, or any of them, in any efforts they may make for their actual freedom.
}

Emancipation Proclamation, January 1, 1863; Presidential Proclamations, 1791-1991; Record Group 11; General Records of the United States Govemment; National Archives, http:/www.ourdocuments.gov/ doc.php?doc $=34 \&$ page $=$ transcript.

${ }^{111}$ In 1863, the South was in rebellion, so the Proclamation did not become effective until after they had lost the war.

\footnotetext{
${ }^{112}$ GuILD, supra note 3, at 42. President Thomas Jefferson freed several slaves in the codicil to his last will and testament. One of them was Burwell Colbert, one of his most trusted slaves who had served as his butler and personal servant. In 1812, Jefferson began paying an annual $\$ 20$ gratuity to Burwell. Jefferson sometimes borrowed money from him. See Founders Online, Thomas Jefferson to James Leitch, 15 February 1812, NAT'L ARCHIVES \& RECORDS ADMIN., http://founders.archives.gov/ documents/Jefferson/03-04-02-0386 (last visited Mar. 1, 2016). Burwell Colbert was the grandson of Elizabeth Hemings, who was the mother of Sally Hemings, Jefferson's concubine. See GoRdonREED, THE HEMINGES, supra note 71, at 668-69 (showing the Hemings Family Tree).

${ }^{113}$ RUSSELL, supra note 17 , at 61 .

${ }^{114} \mathrm{Id}$.

115 Last Will \& Testament of Benjamin Crawley (May 17, 1793) (on file with the author)

${ }^{116}$ Id.
} 
Professor Russell details several incidents where the Virginia legislature freed people for meritorious service in the Revolutionary War, for example. ${ }^{17}$ Virginia essentially took the position that if it had the power to make a slave, it also possessed the power to "unmake a slave."118 The colonial legislature would sometimes validate wills that purported to free slaves before 1782. For example, a special legislative act manumitted the slaves of John Barr who had been set free by his will, but specified that the act should establish no precedent. ${ }^{119}$

Courts also wrestled with the concept of private manumission by will or deed. One judge said that by freeing a slave, the master was not gifting the person property because slaves could not own property, but rather manumission "is the exoneration of a human being from the bonds which our institutions have fastened upon him." 120

As for the third category Professor Russell mentioned-mulatto children born to white mothers - the Virginia legislature passed a law in 1705 stating that indentured women servants who had illegitimate children by a Negro or mulatto, were liable for a fine or could be sold as a servant for five years at the expiration of her original indenture. ${ }^{121}$ Her children were to be bound out as servants until the age of thirty-one. ${ }^{122} \mathrm{By} 1765$, the legislature had lowered the term and required that the illegitimate boys of women servants and blacks, or of free Christian white women by blacks, were to be bound out until they reached age twenty-one. ${ }^{123}$ lllegitimate girls became indentured servants until they reached the age of eighteen. ${ }^{124}$

However, because of protests from the public against this severe restriction on property rights, ${ }^{125}$ Virginia removed the prohibition against emancipation in 1782. ${ }^{126}$ These protests arose, according to Professor Russell, because the

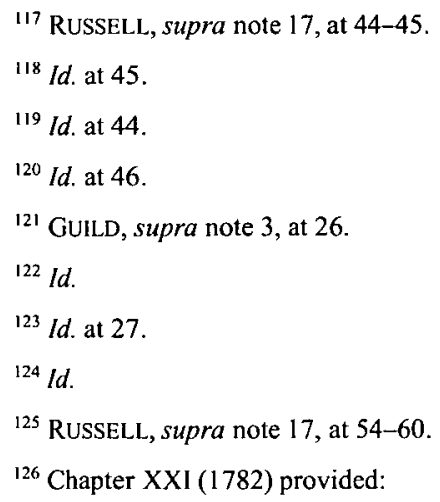

It is lawful for any person by last will and testament or other instrument in writing sealed and witnessed to emancipate and set free his slave or slaves.

All slaves so set free, not being of sound mind and body, or being above forty-five years of age, or males under twenty-one and females under eighteen shall be supported by the persons liberating them.

GuILD, supra note 3, at 61 . Chapter 41 (1792) slightly modified this rule by requiring, "Slaves may be emancipated by an instrument in writing, attested and proved by two witnesses; provided they shall 
prohibition was considered a severe restraint on the rights of men to do whatever they pleased with their property and concerns about keeping individuals in bondage after whites had just won their freedom from England. ${ }^{127}$

These manumissions coupled with births to Free Blacks contributed substantially to the growth of the Virginia population. Just how many Free Blacks were in Virginia between the time of statehood and the Civil War? Table 5 indicates that in 1790, nearly two percent of Virginia's population consisted of Free Blacks, thirty-nine percent of enslaved blacks, and fifty-nine percent of whites.

\begin{tabular}{|l|l|l|l|l|}
\hline \multicolumn{5}{|c|}{ Table 5: The Virginia Population from 1790-1860 } \\
\hline & $\mathbf{1 7 9 0}$ & $\mathbf{1 8 2 0}$ & $\mathbf{1 8 4 0}$ & $\mathbf{1 8 6 0}$ \\
\hline $\begin{array}{l}\text { Free } \\
\text { Blacks }\end{array}$ & $\begin{array}{l}12,866 \\
(1.72 \%)\end{array}$ & $\begin{array}{l}36,875 \\
(3.46 \%)\end{array}$ & $\begin{array}{l}49,841 \\
(4 \%)\end{array}$ & $\begin{array}{l}58,042 \\
(3.6 \%)\end{array}$ \\
\hline $\begin{array}{l}\text { Enslaved } \\
\text { Blacks }\end{array}$ & 292,627 & 425,148 & 448,988 & 490,865 \\
$(39.14 \%)$ & $(40 \%)$ & $(36 \%)$ & $(30.8 \%)$ \\
Whites & 442,117 & 603,381 & 740,968 & $1,047,299$ \\
& $(59.14 \%)$ & $(56.63 \%)$ & $(60 \%)$ & $(65.6 \%)$ \\
\hline Total & 747,610 & $1,065,404$ & $1,239,797$ & $1,596,206$ \\
\hline
\end{tabular}

Altogether, blacks encompassed over forty percent of all individuals living in Virginia in 1790 . On the eve of the Civil War in 1860, the Free Black population had doubled to nearly four percent, but because the enslaved population had declined, the percentage of total blacks in Virginia had dropped to thirty-four percent while the white population had risen to nearly sixty-six percent. One commentator stated that this shift occurred because "from 1830 to 1860 , Virginia sold over three hundred thousand slaves to buyers outside the state-a diaspora comparable in scope to some of the great mass migrations of history." ${ }^{29}$ This shift ensured that Virginia would not join "South Carolina in shifting from a predominantly white to a predominantly black population." 130

\footnotetext{
be liable to be taken on execution to satisfy any debt contracted previously by the person so emancipating." Id. at 65 . Thus, ten years later Virginia required witnesses to the written instrument of emancipation and permitted others to take slaves to satisfy debts.

${ }^{127}$ RUSSELL, supra note 17 , at 54-56.

${ }^{128} I d$. at 13.

129 JOHN Chester Miller, The WOLf By the EARS: ThOMAS JefFERSON AND SLAVERY 241 (1991).

${ }^{130} \mathrm{Id}$.
} 
Despite the Free Black's relatively small percentage of overall blacks in the state, according to Professor Russell, "Of the free [N] egro population of the United States, Virginia had about one eighth." 131 Luther Porter Jackson confirms Professor Russell's assessment in his book, Free Negro Labor and Property Holding in Virginia, 1830-1860:

The free Negro element in Virginia was always relatively large. In 1790 and 1800 Virginia led all the states in the number of free Negroes; in 1830 and again in 1860 it held second place. At this last date the number of free Negroes in Virginia was almost as great as the entire number of blacks in New York and New England combined. In fact, one-eighth of all free Negroes in the nation lived in Virginia. ${ }^{132}$

In comparison, what was the percentage of the black population in other states? As Table 6 indicates, in 1790 it ranged from substantially less than one percent in Vermont to nearly forty-four percent in South Carolina, indicating the fewest numbers of blacks resided in Vermont while the most lived in South Carolina. Immediately after the Revolutionary War, Virginia, by contrast, had the second largest overall percentage of blacks living within its environs. Even Vermont's tiny percentage would indicate the presence of at least one person or family of African descent within its territorial boundaries. Perhaps not surprisingly, the upper South possessed more Free Blacks than the Lower South.

\begin{tabular}{|c|c|c|c|c|c|c|}
\hline \multicolumn{7}{|c|}{ Table 6: Percentage of Black Population in $1790^{133}$} \\
\hline $\begin{array}{l}\text { New } \\
\text { England }\end{array}$ & $\begin{array}{l}\mathrm{ME} \\
0.6 \%\end{array}$ & $\begin{array}{l}\text { NH } \\
0.6 \%\end{array}$ & $\begin{array}{l}\text { VT } \\
0.3 \%\end{array}$ & $\begin{array}{l}\text { MA } \\
1.4 \%\end{array}$ & $\begin{array}{l}\mathrm{RI} \\
6.3 \%\end{array}$ & $\begin{array}{l}\text { CT } \\
2.3 \%\end{array}$ \\
\hline $\begin{array}{l}\text { Middle } \\
\text { States }\end{array}$ & $\begin{array}{l}\text { NY } \\
7.6 \%\end{array}$ & $\begin{array}{l}\mathrm{NJ} \\
7.7 \%\end{array}$ & $\begin{array}{l}\text { PA } \\
2.4 \%\end{array}$ & & & \\
\hline $\begin{array}{l}\text { Upper } \\
\text { South }\end{array}$ & $\begin{array}{l}\mathrm{DE} \\
21.6 \%\end{array}$ & $\begin{array}{l}\text { MD } \\
34.7 \%\end{array}$ & $\begin{array}{l}\text { VA } \\
40.9 \%\end{array}$ & $\begin{array}{l}\mathrm{NC} \\
26.8 \%\end{array}$ & $\begin{array}{l}\text { KY } \\
17.0 \%\end{array}$ & $\begin{array}{l}\text { TN } \\
10.6 \%\end{array}$ \\
\hline $\begin{array}{l}\text { Lower } \\
\text { South }\end{array}$ & $\begin{array}{l}\mathrm{SC} \\
43.7 \%\end{array}$ & $\begin{array}{l}\text { GA } \\
35.9 \%\end{array}$ & & & & \\
\hline
\end{tabular}

This form of slavery was harsher in states like Mississippi and Louisiana.

\footnotetext{
131 RUSSELL, supra note 17, at 9.

132 LUTHER PORTER JaCKSON, FReE NEgro LABOR AND Property HOLdING IN VIRGINIA, 1830$1860, \mathrm{IX}-\mathrm{X}(1968)$.

${ }^{133}$ BERLIN, supra note 6 , at 23.
} 
In his book, Twelve Years a Slave, Solomon Northup who had been sold to a Master Epps in Louisiana, presented a harsh account of whippings for failing to produce a cotton-picking quota or just about anything that irritated his master. ${ }^{134}$ Reading Northup's book makes clear that whether slave or free, a black person in the South was better off being in Virginia than in the lower South during the antebellum period. Virginia even enacted a statute that prohibited Free Blacks and mulattoes from being stolen, and was designed, according to the court in Davenport $v$. Com. ${ }^{135}$ to protect them in the enjoyment of their freedom. The Revolutionary War had an impact on Virginia's approach to manumission that did not seem to affect states like Louisiana and Mississippi.

\section{THE EFFECT OF THE REVOLUTIONARY WAR ON MANUMISSION RESTRICTIONS}

Both immediately before and following the Revolutionary War, the movement to permit manumissions increased. The arguments for manumission were based on religious grounds and on secular concerns about keeping others oppressed after the whites had just obtained their freedom. ${ }^{136}$

The Quakers and the Methodists were at the forefront of the religious movement to repeal restrictions on manumission. ${ }^{137}$ Professor Russell maintained, "Many Quakers in Virginia had been owners of slaves up to the period of the Revolutionary War, but they were among the first to recognize and admit fully the humanity of the $[\mathrm{N}]$ egro and the injustice of depriving him of his right to

${ }^{134}$ NORTHUP, supra note 12, at 119. In Twelve Years a Slave, Solomon Northup writes,

The whippings were just as severe as if we had gone forth in the morning, strengthened and invigorated by a night's repose. Indeed, after such frantic revels, he was always more sour and savage than before, punishing for slighter causes, and using the whip with increased and more vindictive energy. Ten years I toiled for that man without reward. Ten years of my incessant labor has contributed to increase the bulk of his possessions. Ten years I was compelled to address him with down-cast eyes and uncovered head--in the attitude and language of a slave. I was indebted to him for nothing, save undeserved abuse and stripes.

Id.

${ }^{135}$ Davenport v. Commonwealth, 28 Va. 588, 592 (1829). According to the court,

to preserve that freedom it was necessary to guard them against two classes of persons; 1st those who might obtain a wrongful or illegal possession of them for the purpose of converting them to their own use; 2 ndly, those who having a rightful possession, or at least a possession, not illegal, might sell them as slaves.

Id. at 593. Davenport was indicted and convicted of stealing a free mulatto boy that he knew at the time was free. The court found that the kidnapping completed the offence and that knowledge of the boy's freedom need not be proven.

${ }^{136}$ RUSSELL, supra note 17 , at 55-56.

${ }^{137}$ Id. at 57. 
freedom."138 Many Methodists, like the Quakers, "refused to own or sell slaves."139

Professor Russell uncovered an article in the Virginia Gazette in 1767 that began with: "Long and serious reflections upon the nature and consequences of slavery, ... now, as freedom is unquestionably the birth-right of all mankind, Africans as well as Europeans, to keep the former in a state of slavery is a constant violation of the right and therefore justice." 140 Some petitioners argued to the Virginia legislature, "The glorious and ever memorable Revolution, . . . can be justified on no other principles, but what do plead with still greater force for the emancipation of our slaves in proportion as the oppression exercised over them exceeds the oppression formerly exercised over the United States by Great Britain."141

Professor Russell also wrote that the secular drive to permit manumission was proposed by a "younger set of men, who represented the liberal ideas of the English and French thought of that time, and prominent among them was Thomas Jefferson." 142 In 1769, as a member of the legislature, Thomas Jefferson seconded a motion to remove the restrictions on voluntary manumission. ${ }^{143}$ Russell opined that men like Thomas Jefferson were "due much of the credit for the support in the legislature of the proposition which was enacted into law in May, 1782, bearing the title, "An act to authorize the manumission of slaves." 144 As discussed herein, Jefferson would later take advantage of the removal of manumission restrictions to free several of Sally Hemings relatives, including two of their sons. ${ }^{145}$ Moreover, some of Jefferson's other plans for the abolition of slavery did not succeed. He wanted to require that all children born of slave parents after 1800

\footnotetext{
${ }^{138} / d$. at 57-58 (explaining that Quakers sought to convince others of the evil of the practice of slavery and its "inconsistency with our Christian profession").

${ }^{139}$ Id. at 58 .

${ }^{140}$ Id. at 54-55 (citing Virginia Gazette, March 19, 1767, quoted in Views of American Slavery, Taken a Century Ago, p. 109).

141 RUSSELL, supra note 17, at 55-56 (quoting MS. Petitions, Hanover County, 1785; Frederick County, 1786, A6340).

142 Id. at 59.

143 Id. at 55.

${ }^{144} I d$. at 59 . The act provided:
}

Be it enacted That it shall hereafter be lawful for any person by his or her last will and testament, or by any other instrument in writing, under his or her hand and seal attested and proved in the county court by two witnesses, or acknowledged by the party in the court of the county where he or she resides, to emancipate and set free his or her slaves, or any of them, who shall thereupon ... enjoy as full freedom as if they had been particularly named and freed by this act.

Id. at 59, n. 64 (internal citations deleted).

145 See supra notes $41-42$, and accompanying text for information about Jefferson freeing Sally Hemings' relatives through the codicil to his will. 
be set free after attaining adulthood, being trained as apprentices, and then deported from the state. ${ }^{146}$

The colonial legislature became even more generous toward permitting manumissions after 1782. In 1783, they expressed gratitude to every black who fought or served as a freeman in the late war by pledging "the utmost protection of the State in the enjoyment of the freedom he had helped to gain." 147 Slaves who served in the Revolutionary War were also set free, at public expense. ${ }^{148}$

During the late 1700 s, thousands of slaves, like the author's ancestors, were granted their freedom, either by deed or will. Moreover, Russell wrote, "This period from 1782 to 1806 was the time when manumission was most popular in Virginia, and is unique in the history of slavery in the State as being the only period when manumission went on at a rapid rate without legal restraint." 149 When Benjamin Crawley freed the author's ancestor Gideon Hill and several of his relatives, this was part of a wave of private manumissions.

The increase in the numbers of Free Blacks throughout Virginia, unfortunately led to concern and another trend toward retrenchment of legal rights for Free Blacks. As the numbers of Free Blacks grew in certain communities, their presence caused social consternation in the Virginia legislature. When the legislature began to restrict manumissions in 1691, it threatened slaves with banishment after being set free. ${ }^{150}$ This was to happen again.

A rebellion led by a slave named Gabriel in 1800 began another era of retrenchment that sought to limit the existence of Free Blacks in Virginia because of concern that their mere presence would encourage enslaved blacks to want freedom as well. ${ }^{151}$ In 1806 , Virginia legislators passed a law requiring slaves granted freedom to leave Virginia within a year and a day of receiving their emancipation. ${ }^{152}$ This rule was further reinforced in the 1848 criminal code, when the Virginia legislature mandated:

\footnotetext{
${ }^{146}$ MILLER, supra note 129, at 22.

${ }^{147}$ RUSSELL, supra note 17, at 62.

${ }^{148} \mathrm{Id}$.
}

Every [N] $]$ gro who fought or served as a free man in the late war was given in 1783 a legislative pledge of the utmost protection of the State in the enjoyment of the freedom he had helped to gain; and a slave who could prove any honorable service rendered by him to the American cause was freed by special act and at expense of the state.

$$
\begin{aligned}
& { }^{149} \mathrm{Id} \text {. at } 63 . \\
& { }^{150} \mathrm{Id} \text {. at } 51 . \\
& { }^{151} \mathrm{Id} \text {. at } 64-65 \text {. } \\
& { }^{152} \text { GuILD, supra note } 3 \text {, at } 72 \text {. }
\end{aligned}
$$

Slaves brought into this state and kept one year shall be forfeited by the owner, and the right to the slaves shall rest in the overseers of the poor, who shall apprehend such slaves for the benefit of the poor. If any slave hereafter emancipated shall remain within this Commonwealth more than twelve months 


\begin{abstract}
Any person emancipated from slavery since May 1, 1806, or claiming his right to freedom under an ancestor emancipated since that day, who shall remain in the state more than one year after his freedom accrued, and more than one year after he arrives at the age of twenty-one, or more than one year after the revocation of any lawful permission to remain shall forfeit his right to freedom and be sold as a slave. ${ }^{153}$
\end{abstract}

In Ted Maris-Wolf's book, Family Bonds: Free Blacks and Re-enslavement Law in Antebellum Virginia, he writes about a substantial number of Free Blacks who chose to be re-enslaved in order to remain close by their relatives. ${ }^{154}$

After Virginia passed its law encouraging blacks to leave, several northern and southern states passed laws refusing to accept recently freed blacks. The free states included Indiana, Illinois, and Ohio, and the slaveholding states included Missouri, North Carolina, and Tennessee. ${ }^{155}$ Maryland, Kentucky and Delaware passed their restrictive emigration law within a year of Virginia's efforts to encourage Free Blacks to leave, whereas the others passed their laws within twenty-five years of Virginia's harsh legislation. ${ }^{156}$ South Carolina, where upwards of sixty percent of the population was enslaved during the antebellum period, also did not extend a cordial welcome to Virginia's expatriated Free Blacks. ${ }^{157}$

The Acts of 1806 and 1848 discouraged whites from emancipating blacks, and blacks who purchased their enslaved relatives from manumitting them. Black women who acquired their enslaved husbands refrained from freeing them so they would not be forced to leave Virginia, and so did black men who worked diligently to purchase their wives and children. In some instances, the results could be particularly harsh.

The Free Black population increased exponentially as a result of these manumissions. They chose to live in cities not spread evenly across Virginia, but rather tended to concentrate in the eastern half of the state. ${ }^{158}$ In Petersburg, where

after his freedom, he shall forfeit such right, and may be sold by the overseers for the benefit of the poor.

${ }^{153}$ Id. at 117.

154 See generally TEd MARIS-WOLF, FAMILY BONDS: FREE BlaCKS AND RE-ENSLAVEMENT LAW IN ANTEBELLUM VIRGINIA (2015).

155 RUSSELL, supra note 17 , at 72.

${ }^{156} \mathrm{Id}$.

157 HIGGINBOTHAM, supra note 88, at 207 ("The legislature displayed its fear of the rising black population, whether slave or free, in another 1800 act that prohibited the entry into South Carolina of any free Negro or any 'slave of servant or color, [brought in] for sale within this state. ...' Free blacks entering or brought into South Carolina in violation of this act were ordered to be sold after the violation was established by jury verdict.").

${ }^{158}$ RUSSELL, supra note 17, at 13 ("In the mountainous half of the State, which after 1830 contained half of the white population, free $[\mathrm{N}]$ egroes were so scarce as to be an almost negligible social factor .... Of 
Gideon Hill lived and owned a farm of fourteen acres near Cox Road on which he paid taxes, ${ }^{159}$ Free Blacks constituted about a fourth of all blacks living there, and about ten percent of the entire town. By one estimate, in a town that totaled 3,000 people, there were 310 Free Blacks. ${ }^{160}$ By 1830, Petersburg would contain 2,032 Free Blacks, 2,850 slaves, and 3,440 white persons. ${ }^{161}$ By 1860 , Petersburg was home to 3,164 Free Blacks, 5,680 slaves, and a white population that equaled the black population. ${ }^{162}$ Among the landowners in the town at that time were Celia Hill, Gideon's widow, and their son John Hill. ${ }^{163}$ Celia had purchased her land in 1857 for $\$ 775$ and by 1860 it had a value of $\$ 800$, whereas John's land had been purchased in 1856 for $\$ 70$ and had increased in value to $\$ 500 .{ }^{164}$ Perhaps the values are reflected by the location of the land.

As mentioned earlier, a Free Black by the name of Frank died before emancipating his enslaved widow, Patience, and their three children. ${ }^{165}$ It took a successful petition to the legislature to save them from being re-enslaved. Even the legislature acknowledged that Frank had purchased his family with "meritorious industry." 166 The legislature declared, "it is enacted by the General Assembly that Patience and the children shall be free." 167 Frank probably did not free Patience and their children because they would have been forced to leave the state.

Moreover, Professor Russell contended that there may have been some advantages to having an enslaved spouse ${ }^{168} \mathrm{He}$ wrote, "[c]ertainly there was less responsibility upon a husband whose wife and children were slaves and were therefore supported by their white owners." ${ }^{69} \mathrm{He}$ added, "[i]n this manner he will not only have his wife and children supported by the owner, and a lodging provided for himself, but much of his own food will be obtained from his wife and, directly or indirectly, to the loss of her master." ${ }^{170}$ Newly freed blacks who petitioned the legislature to remain in Virginia would often point out that their

the 12,866 free [N]egroes in Virginia in 1790 only 75 resided in Trans-Alleghany, or what is now West Virginia").

${ }^{159}$ Dinwiddie County's General Index to Deeds (Feb. 14, 1840) (on file with the author).

${ }^{160}$ RUSSELL, supra note 17 , at 14.

${ }^{161} I d$. at 14.

${ }^{162}$ Id. at $14-15$.

${ }^{163}$ See JACKSON, supra note 132, app. 1, at 241.

${ }^{164}$ Id.

${ }^{165}$ GuILD, supra note 3, at 96 (reproducing Chapter LVIII from 1810).

${ }^{166} \mathrm{Id}$.

${ }^{167}$ Id.

${ }^{168}$ RUSSELL, supra note 17 , at 132.

${ }^{169} \mathrm{Id}$.

${ }^{170} \mathrm{Id}$. 
wives and children were slaves. ${ }^{171}$ Nevertheless, there seems to have been some legal rules prohibiting marriage between free black women and enslaved men. ${ }^{172}$

Many other petitions were brought seeking to permit Free Blacks to remain in the state. Some were successful while others failed. For example, in 1810, the legislature permitted Pompey Branch, to remain as a free person of color in the state. ${ }^{173}$ In 1811 , the legislature permitted Jingo and James Lott, free men of color, to remain in the state and also Hannah, who was liberated by William Turner, to remain in the state. ${ }^{174}$ But the following year, while it honored the provision of a will freeing the slave Jacob, the Virginia legislature refused to permit him to remain in the state. ${ }^{175}$ Without legislative history, it's difficult to determine why the legislature granted certain petitions but denied others.

This cycle of permissiveness and restrictiveness toward manumissions repeated itself throughout the colonial and antebellum periods. The unintended consequences for Free Blacks created unfortunate family dynamics whereby they felt forced to keep their relatives enslaved to stay in the state.

The phase that began in the spirit of the Revolutionary War which had brought freedom to whites from their oppressors lasted a mere two decades. It ended when enslaved blacks sought their freedom by rebelling from their bondage condition.

\section{SOCIAL INTERACTIONS BETWEEN FREE BLACKS AND WHITES}

Throughout the antebellum period and up until the Civil War, Free Blacks and whites socialized in Virginia as neighbors, conducted business, and sometimes, as discussed earlier, engaged in forbidden coupling. As mentioned before, there were Free Blacks who were accorded privileges equal to those of whites. ${ }^{176}$ Some Free Blacks became "prosperous owners of personal and real property." 177 There is even documentation supporting the proposition that many single free black women were landowners during the antebellum period. ${ }^{178}$ This indicates an early colonial period of easy interactions between the races.

\footnotetext{
${ }^{171}$ Id. at 133.

${ }^{172}$ See Ellen D. Katz, African-American Freedom in Antebellum Cumberland County, Virginia, 70 CHI.-KENT L. REV. 927, 961-62 (1995). It's possible the population of Free Black women may have exceeded the population of men of the same status. Thus, the Free Black Women who wish to marry may have sought partnering with enslaved men. Their children would be born free, but the enslaved man could be sold by his owner to another part of the country. Id.

${ }^{173}$ GUILD, supra note 3, at 96 (reproducing Chapter LXXVIII from 1810).

${ }^{174}$ Id. at 97 (reproducing Chapter LXXIX-LXXX from 1811).

${ }^{175}$ Id. at 97 (reproducing Chapter CXXVIII from 1812).

${ }^{176}$ RUSSELL, supra note 17 , at 125.

${ }^{177}$ Id.

${ }^{178}$ See Katz, supra note 172, at 961.
} 
This socialization further evidences itself in the number of Virginia citizens who petitioned the legislature to permit newly freed slaves to remain in the state. In his book, Professor Russell mentioned the plea of the inhabitants of Lynchburg for Pleasant Rowan, a free colored carpenter and mechanic, for "'his loss would be felt by the community" and the 120 whites who petitioned to keep Daniel Warner, "a free [N] egro barber of Warrenton." 179 Another appeal filed on behalf of Harriet Cook was signed by nearly 100 whites that included seven justices of the peace, five ex-justices, sixteen merchants, six lawyers and a postmaster. ${ }^{180}$ Their entreaty said, "It would be a serious inconvenience to a number of the citizens of Leesburg to be deprived of her services as a washerwoman and in other capacities in which, in consequence of her gentility, trust-worthiness, and skill she is exceedingly useful." 181 White folks from the town of Halifax pleaded that Fortune Thomas, a free colored woman, had rendered her services for baking cakes and tarts and making candies indispensable." 182 The petitioners added, "she has been earnestly assured by the ladies that they can in no measure dispense with her assistance and that no party or wedding can well be given without great inconvenience should her shop be broken up and discontinued." 183

All of these effective petitions to the legislature confirm the presence of successful businesses run by Free Blacks in the state of Virginia. These were enterprises that were so appreciated by whites that they were willing to battle to keep the owners within Virginia. Because they were free, Pleasant, Daniel, Harriet, and Fortune could employ their skills and talents for the benefit of themselves and their communities.

In some situations, newly freed blacks just chose to remain in the state and they were not apprehended. ${ }^{184}$ No petitions were filed on their behalf. This was merely one instance of several indicating disconnects between the legal rules and their enforcement. In her article African-American Freedom in Antebellum Cumberland County, Virginia, Ellen Katz argued, "white perceptions of free blacks embodied in the state's laws are not readily evident in the daily interactions between whites and free blacks in [Cumberland] county."185

These friendly connections occurred at a time when Virginia slowly stripped away more rights from Free Blacks from 1802 to 1865 , including their privileges to own weapons, freely assemble, and travel within and outside of the state. Ira Berlin writes in his forward to Paul Heinegg's book, "[F]ree blacks found their legal rights circumscribed. In various colonies, they were barred from voting,

\footnotetext{
${ }^{179}$ RUSSELL, supra note 17 , at 153.

${ }^{180} \mathrm{Id}$.

${ }^{181} I d$. at $153-54$.

182 Id. at 154.

${ }^{183} \mathrm{Id}$.

${ }^{184} I d$. at 151 .

${ }^{185}$ See Katz, supra note 172 , at 933.
} 
sitting on juries, serving in the militia, carrying guns, owning dogs, or testifying against whites."186

One would probably assume that if blacks could not testify against white oppressors, this would make it almost impossible to convict a white person for harming a black person. However, there were instances of whites who witnessed crimes against blacks and helped them. In Cato v. Scruggs, after Lawrence Cato, a Free Black, sued Valentine Scruggs, a white woman, for illegally entering and detaining his five-acre estate, his white neighbors testified on his behalf. An allwhite jury decided he could regain possession of his property and be reimbursed by Scruggs for his cost in suing her. ${ }^{187}$ In 1834, another Free Black property owner, Judith Lipscomb, received a jury verdict in her favor. ${ }^{188}$

But there were many other incidents where Free Blacks were less successful in their attempts to bring whites to justice for violating their legal rights. ${ }^{189}$ For example, Ellen Katz cites the 1847 lawsuit that Kitty Lipscomb, a Free Black female property holder, filed against William Bradley, a white man, after he allegedly assaulted her. ${ }^{100}$ The complaint alleged that Bradley beat Lipscomb with "clubs, sticks, and fists." 191 Lipscomb sought $\$ 200$ in damages, and three whites were summoned to testify. The jury found in favor of Lipscomb but only awarded her damages of $\$ 6.66$ plus costs. ${ }^{192}$

In their article, "Rather than Free": Free Blacks in Colonial and Antebellum Virginia, Judge Leon Higginbotham and his then law clerk Greer C. Bosworth analyze the denial of the rights to hold public office, to vote, to possess weapons, to travel, and to associate with other blacks, both the free and the enslaved. ${ }^{193}$ When the Virginia legislature mandated that if Free Blacks left Virginia to obtain an education in the North they could not return to the state, Higginbotham and Bosworth considered these rules were "enacted out of fear that an enlightened free black population threatened both white Virginians' property interests and the stability of slavery." 194

Such rules discouraged Free Blacks from sending their children to northern states to be educated because they could not return. Since Virginia had passed prior restrictions on Free Blacks' ability to obtain an education within the state,




this ensured that most of the Free Blacks would remain illiterate unless they were taught by literate relatives or by religious orders such as the Quakers.

In several instances, the many legal rules governing Free Blacks appear to have been used as models for the Jim Crow ${ }^{195}$ restrictions that applied to all blacks freed after 1865 .

Interestingly, one right Free Blacks never lost was the right to own property. ${ }^{196}$ In his work, John Hope Franklin documented that Free Blacks possessed full rights to transfer and devise property. ${ }^{197}$ In her article entitled African-American Freedom in Antebellum Cumberland County, Virginia, Ellen Katz wrote, " $[\mathrm{t}]$ he one realm the Virginia state legislature never racially restricted during the antebellum period-land ownership and the rights accompanying itappears to have remained open and accessible to Cumberland County's free black residents, who engaged in numerous land transactions during this period." ${ }^{198} \mathrm{Kat} z$ documented, "seventy-six acquisitions of land by free black residents of Cumberland County between 1782 and 1863[.]"199

It is because Virginia declined to racially restrict land purchases that the author was able to track her ancestor Gideon Hill's land acquisitions and sales during the first half of the 1800s. In Dinwiddie County's General Index to Deeds, for example, the author located Gideon Hill's name as grantor and a Green $\mathbf{J ~ H ~ W}$ Reames Tr. as grantee for a Trust that was recorded on February 17, 1840. ${ }^{200}$ The author found a deed in which Gideon's heirs (his wife Celia, and his children Mary, Julia, Edwin, Nancy, Gid, Sam and Melville Hill) sold his property after his passing in $1856{ }^{201}$ The author also tracked land purchases by other ancestors and collateral relatives in Texas, Oklahoma, Wyoming, and Arizona.

Virginia's permissive approach to property rights were not followed in the southern state of South Carolina. In her book, Amelioration and Empire, Christa Dierksheide wrote about South Carolina, the state with the largest overall percentage of blacks: "[I]n 1822, the legislature passed laws that . . . levied an annual tax of $\$ 50$ on each free black man, prevented free blacks from re-entering the state after they had left, and stipulated that all free blacks must have white

195 "Jim Crow was not a person, yet affected the lives of millions of people. Named after a popular 19th-century minstrel song that stereotyped African Americans, 'Jim Crow' came to personify the system of government-sanctioned racial oppression and segregation in the United States." The Rise and Fall of Jim Crow, PBS, http://www.pbs.org/wnet/jimcrow/ (last visited Oct. 12, 2015).

${ }^{196}$ See JACKSON, supra note 132 , at $\mathrm{xx}$.

${ }^{197}$ See Katz, supra note 172, at 930-31 (citing John H. Franklin, Free Negro in the Economic Life of Ante-bellum North Carolina (pt. I), 19 N.C. HisT. REV. 239, 366-67 (1942)).

${ }^{198}$ Katz, supra note 172 , at 928.

${ }^{199}$ Id.

${ }^{200}$ Dinwiddie County's General Index to Deeds (Feb. 14, 1840) (on file with the author).

201 Id. on Nov. $11,1856$. 
guardians or face expulsion from the state." 202 Dierksheide considered the Negro Seaman's Act to be even more draconian because it "allowed local authorities to imprison free black sailors while their ships remained docked at a South Carolina port." 203

As Ira Berlin, author of Slaves Without Masters, wrote in his introduction to Twelve Years a Slave, "Northup makes clear that the slave owner's authority could be maintained only by terrorizing black people with relentless physical and psychological violence." 204 Although Berlin referred to Free Blacks as "slaves without masters" in the title to his book and in its content, ${ }^{205}$ from a black person's perspective there was a huge difference between being free and being enslaved. It is this difference that made Solomon Northup's book, Twelve Years a Slave, and the major motion picture, 12 Years a Slave, so compelling a literary and entertainment experience. Northup was someone who had been born free, only to be kidnapped by those seeking profit from selling him into slavery. ${ }^{206}$

In his book, Freedom Has a Face, Professor Kirt von Daacke questioned the view of Free Blacks "as only nominally free and trapped in a precarious existence" in Berlin's book and in Ulrich Bonnell Phillips' work, American Negro Slavery. ${ }^{207}$ Von Daacke preferred, instead, to follow the growing body of scholarship that highlighted the economic freedoms and opportunities available to Free Blacks. ${ }^{208}$ He noted that some scholars have found a "startling degree of economic and financial success among individual African Americans. ${ }^{209}$ To lend further credence to this view of Free Blacks, von Daacke examined the economic and social successes, as well as failures, of Free Blacks in one rural antebellum county in Virginia. ${ }^{210}$

Berlin, on the other hand, also opined, "[n]o matter how hard whites squeezed black liberty, the irreducible differences between freedom and slavery remained. Freedom allowed blacks to reap the rewards of their own labor, to develop a far richer social life, and to enjoy the many intangible benefits of liberty." ${ }^{211}$ Further,




"[w]ith hard work, skill, and luck, some free Negroes climbed off the floor of Southern society, acquired wealth and social standing." 212

\section{CONCLUSION}

As difficult as the lives of Free Blacks were because of the increasing legal restrictions they faced, their privileges far exceeded those of the enslaved. Their story reminds us of what might have been had Virginia not stripped Free Blacks of the right to vote, to educate their children, to freely associate, and to travel. Would Free Blacks participating in the political process have created a more just world for everyone? Some evidence that this might have been so can be inferred when during the Reconstruction Era ${ }^{213}$ Free Black legislators led the charge for public education for everyone. It begs the question: would we have needed a Civil War if states like Virginia had not transitioned Africans from servants for a term to servants for life? Could the 600,000 lives that were lost during "The War of Northern Aggression," as the Southerner's refer to conflict between the states, been saved?

About Free Blacks, Frederick Douglas wrote, "The most telling, the most killing refutation of slavery, is the presentation of an industrious, enterprising, upright, thrifty, and intelligent free black population."214 An example of this industriousness can be found by the activities of James Hill, a relative of Gideon Hill, who was also freed by Benjamin Crawley on January 25, 1787 in the same deed of emancipation. ${ }^{215}$ After receiving his freedom, James Hill purchased his wife Sarah and her two children Sally and Moses from a William Mosely of Chesterfield County, Virginia, on March 1, 1798. James and Sarah had two additional children together before she died. In 1812, James Hill freed all four children by deed in Tennessee where he had subsequently moved. ${ }^{216}$ To save money to purchase his wife and her two children took financial diligence, and then to set all four of her biological children free was a testament to James Hill's generosity of spirit.

History has written its script, and it cannot be altered. The author submits that the public has an obligation to learn from what happened to the Free Blacks of Virginia to diminish the chances of repeating the mistakes of antiquity.

\footnotetext{
${ }^{212} \mathrm{ld}$.

${ }^{213}$ Eric Foner, Why Reconstruction Matters, N.Y. TIMES (Mar. 28, 2015), http://www.nytimes.com/ 2015/03/29/opinion/sunday/why-reconstruction-matters.html?_r=0 (explaining that "[r]econstruction refers to the period, generally dated from 1865 to 1877 , during which the nation's laws and Constitution were rewritten to guarantee the basic rights of the former slaves, and biracial governments came to power throughout the defeated Confederacy").

214 David Brion Davis, The Problem of Slavery in the Age of Emancipation 193 (2014) (quoting Frederick Douglas).

215 albert L. Johnson JR., Minute Book Genealogy of Williamson County, Tennessee (1799-1865) 129 (document on file with the author).

${ }^{216}$ Id.
} 
